\title{
Dobrí Slováci, dobrí občania svojej krajiny? Vojvodinskí Slováci na periférii slovenského a srbského nacionalizmu
}

\author{
Good Slovaks, good citizens of their country? Slovaks of Vojvodina on \\ the periphery of Slovak and Serbian nationalisms
}

DOI: 10.31577/EtnoRozpra.2021.28.2.05

\section{Juraj Marušiak - Sanja Zlatanović}

\begin{abstract}
The topic of the paper is the perception of members of the Slovak community in Vojvodina in Slovak and Serbian society. The paper analyses the content of narratives that are created about members of the community and the way they are created. In the Slovak environment, the image of the community is constructed mainly from "above", through historical and political discourses, while its presence has been disappearing from the Slovak consciousness since the second half of the 20th century. In the Serbian environment, its image is shaped mainly from "below", on the basis of immediate interactions between its members and the majority population.
\end{abstract}

\section{Key words}

Slovakia, Serbia, Slovak community in Vojvodina, identification processes, Alföld (Lower Land); Felvidék (Upper Land)

Klúčové slová

Slovensko, Srbsko, slovenská komunita vo Vojvodine, identifikačné procesy, Dolná zem, Horná zem

\section{Acknowledgement}

Článok bol vypracovaný v rámci projektu VEGA 2/0046/19 Obraz "Iného“ v slovenskej politike po roku 1989 a medziakademického bilaterálneho projektu Mobility SASASAS-21-03 „Slovensko a slovenská komunita vo Vojvodine: vnútroetnické vztahy a hranice"

\section{Kontakt / Contact}

58 Mgr. Juraj Marušiak, PhD., Ústav politických vied SAV, Slovenská akadémia vied, 
Dúbravská cesta 9, Bratislava, 84104 Bratislava, Slovenská republika, e-mail: juraj.marusiak@savba.sk

\section{ORCID (iD https://orcid.org/0000-0003-3972-8165}

Sanja Zlatanović, PhD., Institute of Ethnography, Serbian Academy of Sciences and Arts, Kneza Mihaila 36, Belgrade, Serbia, email: sanja.zlatanovic@ei.sanu.ac.rs

ORCID (iD) https://orcid.org/0000-0003-2268-0257

\section{Ako citovat' / How to cite}

Marušiak, J. a Zlatanović, S. (2021). Dobrí Slováci, dobrí občania svojej krajiny? Vojvodinskí Slováci na periférii slovenského a srbského nacionalizmu. Etnologické rozpravy, 28(2), 58-64. https://doi.org/10.31577/EtnoRozpra.2021.28.2.05

Oblast', označovaná v slovenskej literatúre a historiografii ako tzv. Dolná zem, sa stala predmetom kolonizácie slovenského obyvatel'stva z niekdajšieho Horného Uhorska, resp. Hornej zeme, od 18. storočia. Išlo o kolonizáciu vnútroštátnu, v rámci multietnického Uhorského král'ovstva, čo ovplyvnilo aj identifikačné procesy tamojšieho obyvatel'stva. Na druhej strane, naratív o „dolnozemských Slovákoch“ bol frekventovaný predovšetkým v publicistike a literatúre „hornozemských Slovákov“ (Babiak, 2018). Vzhl'adom na špecifický charakter slovenského osídlenia na tzv. Dolnej zemi, ktoré nemá kompaktný charakter, ale naopak, je charakteristické vytváraním jazykových a etnických enkláv (ostrovov), obkolesených sídlami s prevahou obyvatel'stva, hlásiaceho sa k iným národnostiam (Botík, 2011: 14-15), možno v prípade niektorých „slovenských“ lokalít, ako napr. Békešská Čaba, hovorit’ o prevahe konfesionálnej a následne lokálnej sebaidentifikácie (Divičanová, 2007). Snahy dolnozemských slovenských kultúrnych a politických elít o vytvorenie spoločného „dolnozemského“ slovenského povedomia sú relatívne mladého dáta, ich výrazom bolo napr. vydávanie časopisu Dolnozemský Slovák v rokoch 1902 - 1920 (Hlavatá, 2019). Zmena mocenských pomerov v súvislosti s rozpadom Rakúsko-Uhorskej monarchie v roku 1918 teda ovplyvnila aj označovanie príslušníkov skúmanej komunity, z ktorých sa stali v závislosti od ich štátnej, resp. teritoriálnej príslušnosti, mad’arskí, rumunskí, bulharskí, resp. juhoslovanskí Slováci a po rozpade Juhoslávie v roku 1991 Slováci srbskí (vojvodinskî), resp. chorvátski (Babiak, 2018). Zmena štátnych hraníc uvedenú komunitu rozdelila a napriek blízkosti tradičnej kultúry, identifikačné procesy v prostredí príslušníkov slovenských komunít v jednotlivých štátoch nadobudli odlišnú dynamiku. Podobne diferencovaný prístup v závislosti od vztahov s novovytvorenými štátmi musela volit’ aj ČSR, resp. po roku 1993 samostatné Slovensko. Mocenské vzt’ahy a faktory dominancie tak ovplyvnili nielen sebaidentifikáciu príslušníkov komunity, resp. po roku 1918 už komunít dolnozemských Slovákov, ale aj ich percepciu zo strany „materskej krajiny“ a jej politiku voči nim (porovn. Jenkins, 2008: 23, 53). Z hl'adiska definovania kritérií „slovenskosti“ sa totiž práve ČSR (Slovensko), t.j. niekdajšia Horná zem, stala dominujúcim aktérom.

Ako poukazuje J. Botík, v minulosti, v čase formovania uvedených dolnozemských slovenských komunít, $v$ mnohých prípadoch išlo o relatívne vnútorne kompaktné, etnicky 
homogénne ostrovy (regióny, dediny a ich časti, ulice), preto etnický a kultúrny vývoj ich obyvatel'stva bol $v$ týchto ostrovoch $v$ mnohom zhodný $s$ vývinom na materskom etnickom území. Obraz dolnozemských Slovákov korešpondoval s obrazom Slovákov z Hornej zeme ako prevažne rurálnej populácie, čo bolo nielen dôsledkom ich sociálnej štruktúry, ale aj sociálnej reprezentácie Slovákov, ako ju šírila napr. slovenská i mad’arská krásna literatúra. Faktorom, ktorý prispieval k udržaniu jeho slovenského charakteru z hladiska jazyka, národného vedomia, pomenovania i sebaidentifikácie či rozmanitých prejavov materiálnej i duchovnej kultúry (Botík, 2011: 14-15), bolo aj prevažujúce evanjelické vierovyznanie (s malou katolíckou menšinou v obci Selenča), odlišné od náboženstva okolitého obyvatel'stva (katolicizmus, kalvinizmus a pravoslávie). Hoci sa viacerí autori nazdávajú, že evanjelická cirkev, najmä v období dualizmu, patrila medzi „jeden z najúčinnejších prostriedkov mad’arizácie“ (Viršinská, 2010: 47; Pivková, 2013: 336-337), vysoký počet slovenských veriacich spôsoboval, že sa v období pred revolúciou 1848/49 a neskôr, po likvidácii Matice slovenskej a slovenských gymnázií (1874-1875), stala de facto jedinou slovenskou národnou inštitúciou (pozri Kónya a kol., 2014; Marušiak, 2016).

Aj počas trvania habsburskej monarchie geografický faktor spôsoboval, že tzv. dolnozemskí Slováci boli vnímaní ako geograficky i kultúrne špecifická súčast’ slovenského etnika, hoci sa neocitli úplne mimo pozornosti slovenského národnopolitického hnutia. Nemožno ani zabúdat’ na intelektuálny prínos príslušníkov tejto komunity k formujúcej sa slovenskej literatúre a iným druhom kultúry. Vnímanie tejto „subkultúry“, ako ju označuje J. Botík (2011: 17-20) teda oscilovalo medzi zaradením Dolnej zeme do kontextu slovenskej mentálnej geografie, o.i. aj pod názvom „Dolňozemské Slovensko“, ako tento región označil v roku 1862 Ján Kutlík, a vnímaním tamojších Slovákov ako „'miernejších’ oproti radikálnejším 'hornozemcom'“. Od „hornozemcov“ sa odlišovali kolektívnou pamätou, ktorej súčastou bolo „vedomie príchodu, pionierska úloha predkov pri kultivácii krajiny, obraz Slovenska ('Hornej zeme') viac-menej neurčitý, rozmazaný či žiaden" (Kmet', 2012: 222-225). To súviselo s nutnostou kolonistov prispôsobit sa podmienkam novej domoviny, ked' popri tradičnej kultúre, ktorú si priniesli so sebou a obojsmerným transferom kultúrnych hodnôt medzi Dolnou a Hornou zemou, dolnozemskí Slováci vstupovali do interakcií s kultúrami okolitých etník (Botík, 2011: 17-19). Aj preto bola táto subkultúra vnímaná ako viac podliehajúca mad’arizácii, než Horná zem (Kmet', Kunec, 2020). Na druhej strane, už v 60 . rokoch 19. storočia v súvislosti s teritorializáciou slovenského národného hnutia, vyjadrovanou o.i. aj v Memorande národa slovenského (1861), sa v prostredí dolnozemských slovenských intelektuálov objavoval pocit, že „čírymi Slovákmi obývaná“ vlast' na nich zabudla (Babiak, 2018: 123).

V prostredí dolnozemských Slovákov na území súčasnej Vojvodiny sa odohrali viaceré udalosti so zásadným významom pre slovenský národno-emancipačný proces, akými bolo zvolenie Viliama Paulínyho-Tótha (1869-1872) a Milana Hodžu za poslanca Uhorského snemu (1905) za okres Kulpín vd’aka spolupráci s politickou reprezentáciou tamojších Srbov, a napokon aj tzv. Kovačický proces s evanjelickými veriacimi, ktorí v roku 1907 spevom slovenských piesní protestovali proti zavádzaniu mad’arských bohoslužieb v tejto väčšinovo slovenskej obci (Pivková, 2013: 338; Sirácky, 1996). Táto udalost' postupne zostala v tieni udalostí v Černovej (1907) (Holec, 1997), čo súvisí azda nielen s tým, že policajný zásah v Černovej si vyžiadal ludské obete, ale aj s tým, že sa odohral na slovenskom „materskom“ území, a nie v kultúrnej enkláve a zároveň sa dotýkal majoritného, 
katolíckeho obyvatel'stva, ktorého reprezentácia sa práve v uvedenom období začala aktívnejšie zapájat’ do slovenského národného hnutia.

Zástupcovia Slovákov zo súčasnej Vojvodiny sa aktívne podiel'ali na rozpade Rakúsko-Uhorska. Ešte 10. novembra 1918 vznikla v Novom Sade Národná rada dolnozemských Slovákov. Jej predstavitelia podporili Vel'ké národné zhromaždenie Srbov, Bunjevcov a ostatných Slovanov v Banáte, Báčke a Baranji 25. novembra 1918, ktoré sa vyslovilo v prospech začlenenia regiónu do Srbského královstva (Gubová Červená, 2019: 80-81). Národná rada dolnozemských Slovákov však zároveň pozdravila vznik nového československého štátu a vyjadrila vôl'u „navždy udržat' styky s matkou zemou slovenskou a jej národným životom“. Zároveň však toto vyhlásenie obsahuje aj obavy z možného zabudnutia, ked’že zostali v dôsledku „krutého osudu“ odtrhnutí od slovenskej vlasti: „hlásime sa čo vzdialené deti o jej lásku a priazeň uist’ujúc o svojej vernej oddanosti“ (Jovankovič, 2019: 144).

Aj po rozpade habsburskej monarchie mal teda vztah dolnozemských a „hornozemských“ Slovákov ambivalentný charakter. To súviselo aj s novou debatou o tom, kto je a kto nie je „dobrý Slovák“ na Slovensku samotnom, s konfliktom medzi „predprevratovými“ Slovákmi, t.j. tými, ktorí boli aktívni v slovenskom národnom hnutí pred rokom 1918 a tzv. novými Slovákmi (Novoslovákmi), ktorí začali aktívnejšie vystupovat’ vo verejnom živote ako Slováci až v novej ČSR. Kým tí prví, do vel'kej miery predstavovaní evanjelikmi, označovali tých druhých za „mad’arónov“, tí druhí zas hovorili o tých „predprevratových“, že sú ako odporcovia slovenskej autonómie čechoslovakisti, centralisti a preto nie dobrí Slováci. V prostredí vojvodinských Slovákov prevažovala pročeskoslovenská orientácia, preto príchod Hlinkovej slovenskej l’udovej strany k moci a vznik Slovenského štátu v roku 1939 prijali chladne. Naopak, mnohí z nich participovali na slovenskom i na juhoslovanskom protifašistickom odboji (Hruboň, 2020: 91-92).

Hoci sa po druhej svetovej vojne ČSR, resp. Slovensko obracalo na vojvodinských Slovákov v rámci programu Mat’ volá, ktorý spočival v reemigrácii Slovákov z Mad’arska, Rumunska a Juhoslávie (Polónyová, 2014), o niekol'ko rokov, po prepuknutí konfliktu medzi ZSSR a Juhosláviou v júni 1948, znova prestali byt' „dobrými Slovákmi.“ S ohl’adom na začlenenie ČSR do sovietskeho bloku a vylúčenie Juhoslávie, sa v 50. rokoch 20. storočia stali komunitou, ktorú obe strany vnímali s podozrením. V neskorších rokoch sa kontakty vojvodinských Slovákov so Slovenskom obmedzili najmä na oblast’ kultúry a čiastočne školstva pre potreby rozvoja a udržiavania menšinových kultúrnych a vzdelávacích inštitúcií, resp. na kontakty folklórnych súborov. Aj vzhl'adom na odlišnú politickú a intelektuálnu atmosféru v oboch štátoch však postupne zo slovenského literárneho kontextu začala vypadávat' vojvodinská slovenská literatúra po druhej svetovej vojne. Realita normalizačného Československa zas prispievala k oslabeniu záujmu príslušníkov slovenskej komunity v Juhoslávii o život na Slovensku (Svetlík, 2016: 246-248).

Situácia sa zmenila po prepuknutí vojen v priestore bývalej Juhoslávie v 90. rokoch minulého storočia, v súvislosti s odlišnou dynamikou vývoja na Slovensku, ktoré sa stalo v roku 2004 členom Eú. Po roku 1990 sa začali aj migrácie vojvodinských Slovákov do zahraničia (podobne ako ostatných obyvatel'ov krajín bývalej Juhoslávie), v ich prípade do vel'kej miery práve na Slovensko. Na základe nami publikovaných štúdií, obsahujúcich predbežné výsledky výskumu dôsledkov migračných procesov na život slovenskej 
komunity v Srbsku, môžeme konštatovat', že procesy „zabúdania“ na dolnozemských Slovákov sa na Slovensku po druhej svetovej vojne zintenzívnili, čo naši respondenti pociťujú ako nespravodlivost', pretože na Slovensku sú svojím okolím vnímaní vel'mi často ako Srbi, resp. Juhoslovania, nie však ako Slováci (Zlatanović, Marušiak, 2017; Marušiak, Zlatanović, 2020).

Hoci v Srbsku sú príslušníci tamojšej slovenskej menšiny vnímaní pozitívne, ich obraz nie je vytváraný primárne prostredníctvom politických naratívov. $V$ médiách sa z času na čas objavujú články pripomínajúce, že vojvodinskí Slováci, podobne ako tamojší Srbi a Židia, boli objektom perzekúcie zo strany mad’arských, nemeckých či chorvátskych okupantov (Arhiv Vojvodine, b. d.). Ked'že však nejde o politicky relevantnú komunitu na obyvatel'stve Vojvodiny sa podiel'ajú iba 2,6 percentami (Stojšin, 2015: 29) - prevláda ich stereotypizácia ako prevažne rurálnej menšiny, tvorcov naivného umenia z Kovačice či pracovitých pomocníc v domácnosti, tzv. Zusiek, resp. bedinérok. Prostredníctvom takýchto interakcií sú vnímaní ako poctiví, čistí a pracovití (Lenovský, 2016: 123-124; Marušiak, Zlatanović, 2020). Ich obraz sa formuje na línii nerovnocenných vztahov menšiny a väčšiny, mestského a vidieckeho obyvatel'stva, resp. zamestnávatela a zamestnanca.

Práve ich obraz. ako príslušníkov zanikajúceho „sedliackeho sveta“ (Botík, 2011: 14-15) s bohatým folklórom sa však stáva aj jednou z ciest ich návratu zo zabudnutia do povedomia širšej slovenskej verejnosti, ako to prezentuje napr. Projekt Vojvodina, ktorého iniciátorom je autor programu Zem spieva režisér Peter Nuňéz (Vojvodina, b. d.). Ciel'om projektu je podpora zachovania zanikajúcej komunity Slovákov v Srbsku. Po roku 1862, ked’ sa prvý raz v slovenskej tlači objavil pojem „Dolňozemské Slovensko“, práve v súvislosti s touto folklórnou sútažou odznel v roku 2020 výrok, podla ktorého dolnozemských Slovákov „z hladiska vývoja tradičnej kultúry môžeme považovat' za d’alší región Slovenska" (Handzová, 2020).

Obraz vojvodinských Slovákov na Slovensku je vytváraný v prevažnej miere „zhora“, na základe historických a politických narácií, pričom postupne sa od 19. storočia dostáva táto komunita na perifériu záujmu slovenskej spoločnosti. V Srbsku sa na ich obraze v očiach väčšinového obyvatel'stva podiel'ajú zväčša nepolitické narácie vytvárané „zdola“, s výnimkou pripomínania, že Slovensko neuznalo jednostranné vyhlásenie nezávislosti srbskej provincie Kosovo v roku 2008. V oboch prípadoch sa uvedená komunita ocitá na periférii etnickej, kultúrnej, politickej i sociálnej.

\section{Referencie}

Arhiv Vojvodine. (b. d.). Slovačke žrtve. Novi Sad: Arhiv Vojvodine. https://slovackezrtve.arhivvojvodine.org.rs/

Babiak, M. (2018). Kultúrne dedičstvo vojvodinských Slovákov v kontexte slovenskej kultúry. Muzeológia a kultúrne dedičstvo, 6(2), 121-130.

Botík, J. (2011). Dolnozemskí Slováci: Tri storočia vystahovaleckých osudov, spôsobu života a identity Slovákov v Mad’arsku, Rumunsku, Srbsku a Bulharsku. Nadlak: Vydavatel'stvo Ivan Krasko.

Divičanová, A. (2007). „Békešske Slované, Pilišania, Tirpáci. Varianty regionálnej a lokálnej identity“. In Š. Šutaj, L. Szarka (Eds.), Regionálna a národná identita 
v mad'arskej a slovenskej histórii 18.-20. storočia (s. 104-109). Prešov: Universum.

Gubová Červená, G. (2019). Slováci a vznik Královstva Srbov, Chorvátov a Slovincov v roku 1918. In I. M. Ambruš, P. Hlásnik, B. Unc (Eds.), Dolnozemskí Slováci a rok 1918 (s. 78-85). Nadlak: Ivan Krasko.

Handzová, V. (15. 1. 2020). Zem spieva - dolnozemskí Slováci sú d’alší región Slovenska. Pravda. https://kultura.pravda.sk/film-a-televizia/clanok/542597-zem-spievadolnozemski-slovaci-su-dalsi-region-slovenska/

Hlavatá, R. (2019). Prínos časopisu Dolnozemský Slovák do jazykového a kultúrneho života dolnozemských Slovákov. In I. M. Ambruš, P. Hlásnik, B. Unc (Eds.), Dolnozemskí Slováci a rok 1918 (s. 243-251). Nadlak: Ivan Krasko.

Holec, R. (1997). Tragédia v Černovej a slovenská spoločnost'. Martin: Matica slovenská. Hruboň, A. (2020). „Zblúdilé ovečky národného košiara“. Juhoslovanskí Slováci proti Tisovmu štátu a režimu. In M. Lysý, J. Drábik (Eds.), Tisovi poza chrbát : príbehy odporu voči ludáckemu režimu (s. 73-93). Bratislava: Hadart Publishing.

Jenkins, R. (2008). Rethinking Ethnicity. Arguments and Explorations (2nd edition). Los Angelos - London - New Delhi - Singapure: SAGE Publications.

Jovankovič, S. (2019). Vojvodinskí Slováci a pripojenie Báčky, Banátu a Barane k Srbskému král'ovstvu. In I. M. Ambruš, P. Hlásnik, B. Unc (Eds.), Dolnozemskí Slováci a rok 1918 (s. 141-150). Nadlak: Ivan Krasko.

Kmet', M. (2012). Krátke dejiny dolnozemských Slovákov, 1. zv. Nadlak: Ivan Krasko.

Kmet', M. a Kunec, P. (2020). „Dolňozemské Slovensko“ v reflexii Slovákov v období dualizmu. Krakov: Vydavatel'stvo Spolok Slovákov v Pol'sku.

Kónya, P. a kol. (2014). Dejiny Uhorska. Prešov: Vydavatel'stvo Prešovskej univerzity.

Lenovský, L. (2016). Naši vo svete. Slováci južne od hraníc Slovenska, zv. I. Nadlak: Ivan Krasko.

Marušiak, J. (2016). Slovenský politik Ludovít Štúr v siločiarach európskeho vývoja. Hladanie „slovenského záujmu“. Ročenka zahraničnej politiky Slovenskej republiky 2015. Bratislava: RC SFPA, 115-128.

Marušiak, J. a Zlatanović, S. (2020). Slovakia as a Safe Country - The Perspective of the Slovak Community Members of Vojvodina. Slovenský národopis, 68(2), 136-160. https://doi.org/10.2478/se-2020-0008

Pivková, Z. (2013). Stručný prierez dejinami Evanjelickej cirkvi augsburského vyznania $\checkmark$ Uhorsku (od druhej polovice 19. storočia po rok 1914). In M. Ološtiak, M. Chovanec (Eds.), 8. študentská vedecká konferencia. Zborník plných príspevkov (s. 334-349). Prešov: Prešovská univerzita v Prešove.

Polónyová, S. (2014). Reemigrácie a repatriácie zahraničných Slovákov do vlasti po roku 1945 (tzv. akcia „Mat’ volá“). In M. Šmigel' (Eds.), Migračné procesy Slovenska (1918-1948) (s. 514-535). Banská Bystrica: Belianum, Univerzita Mateja Bela.

Sirácky, J. (1996). Slováci vo Vojvodine: niektoré tajomstvá ich dvestopätdesiatročného trvania. In N. Stojanović, P. Pijanović (Eds.), 250 rokov života Slovákov vo Vojvodine: zborník prác z medzinárodného sympózia v Novom Sade a v Petrovci 6. a 7. októbra 
1995 (s. 7-17). Beograd, Nový Sad: Zavod za udžbenike i nastavna sredstva - Spolok vojvodinskych slovakistov.

Stojšin, S. (2015). Ethnic Diversity of Population in Vojvodina at the Beginning of the 21st Century. European Quarterly of Political Attitudes and Mentalities, 4(2), 25-37.

Svetlík, A. (2016). Kritické čítanie slovenskej vojvodinskej literatúry na Slovensku v druhej polovici 20. a začiatkom 21. storočia. Slovenská literatúra, 63(4), 244-262.

Viršinská, M. (2010). Budapeštianska synoda evanjelickej cirkvi a. v. v Uhorsku (1891 1894) a Slováci. Historický zborník, 20(1), 29-49.

Vojvodina. (b. d.). Projekt podpory a rozvoja slovenskej menšiny vo Vojvodine. Získané 4. 12. 2021, z http://vojvodina.sk/

Zlatanović, S. a Marušiak, J. (2017). „Povratna“ migracija vojvodjanskih Slovaka i pitanje pripadnosti. Bulletin of Institute of Ethnography SASA, 65(3), 653-668. https://doi. org/10.2298/GEl1703653Z 